\title{
Evaluation of Micronutrients in Fenugreek (Trigonella foenum-graecum L.): A Viable Alternative for Micronutrient Supplementation
}

\author{
Naveen Chandra Pant ${ }^{1 *}$, Manisha Tewari ${ }^{2}$, Rakesh Dhoundiyal ${ }^{3}$, C.S. Pandey ${ }^{4}$, \\ J.P. Singh ${ }^{5}$ and Sanjeev Agrawal ${ }^{6}$ \\ ${ }^{1}$ Akal College of Agriculture, Eternal University, Baru Sahib Sirmaur, \\ Himachal Pradesh, India \\ ${ }^{2}$ Department of Zoology, RSM (P.G.) College, Rampur Ghogher, Moradabad, \\ Uttar Pradesh, India \\ ${ }^{3}$ Department of Chemistry, Shri Guru Ram Rai P.G. College, Dehradun, Uttarakhand, India \\ ${ }^{4}$ Department of Agriculture, Dolphin (P.G.) Institute of Biomedical and Natural Sciences, \\ Dehra Dun. 248007, Uttarakhand, India \\ ${ }^{5}$ Department of Vegetable Sciences, College of Agriculture, G. B. P. U. A. \& T. Pantnagar, U. \\ S. Nagar. 264145, Uttarakhand, India \\ ${ }^{6}$ Department of Biochemistry, College of Basic Sciences and Humanties, G. B. P. U. A. \& T. \\ Pantnagar, U. S. Nagar. 264145, Uttarakhand, India \\ *Corresponding author
}

\begin{tabular}{|c|c|}
\hline & A B S T R A C T \\
\hline & \multirow{6}{*}{ 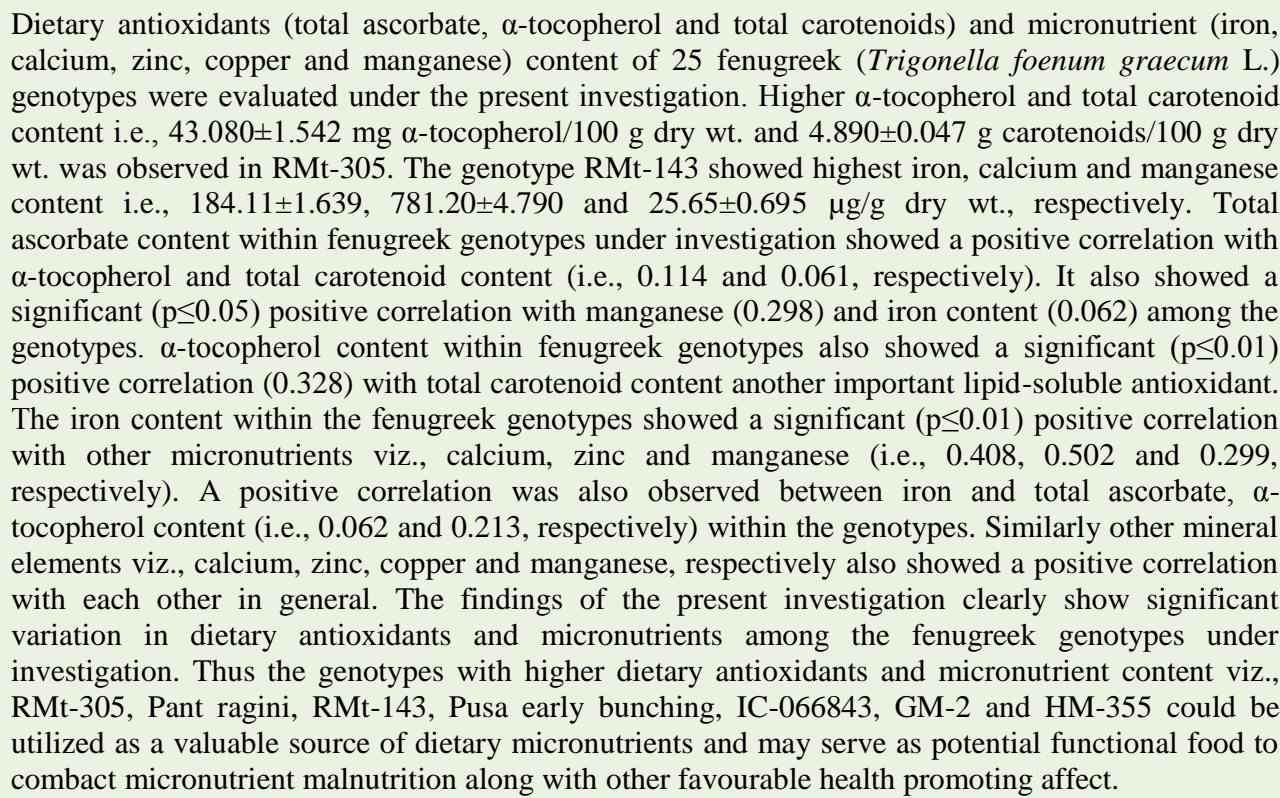 } \\
\hline & \\
\hline $\begin{array}{l}\text { Ascorbate, } \alpha \text {-Tocopherol, } \\
\text { Carotenoid, Dietary } \\
\text { antioxidants, } \\
\text { Micronutrients }\end{array}$ & \\
\hline Article Info & \\
\hline $\begin{array}{l}\text { Accepted: } \\
18 \text { April } 2018 \\
\text { Available Online: } \\
10 \text { May } 2018\end{array}$ & \\
\hline & \\
\hline
\end{tabular}




\section{Introduction}

Deficiencies of micronutrients (minerals and vitamins) have become a major health issue globally. These deficiency disorders leads to poor quality of life, reduced economic productivity and precious human lives lost throughout the world. More than 2 billion people in the world today most of them in developing countries, are estimated to be deficient in key vitamins and minerals, particularly vitamin A, iodine, iron and zinc (Tulchinsky, 2010; Müller and Krawinkel, 2005; Bailey et al., 2015). Most of them live in underdeveloped and developing countries and are typically deficient in more than one micronutrient (Hill and Mkparu, 2015). Deficiencies occur when people do not have access to micronutrient-rich foods such as fruit, vegetables, animal products and fortified foods, usually because of poor quality of diet or unavailability of dietary diversity from different food groups (Burchi et al., 2011; Miller and Welch, 2013). The most vulnerable groups usually suffering from micronutrient deficiencies are pregnant women, lactating women and young children, mainly because of relatively higher requirement of micronutrients and are more susceptible to the harmful consequences of micronutrient deficiencies (Benton, 2008; Fanzo, 2015).

Iron and vitamin A deficiencies are the most prevalent forms of micronutrient malnutrition apart from zinc deficiency (Akeredolu et al., 2011; Bhandari and Banjara, 2015). Iron deficiency is the most common nutritional deficiency in the world, affecting about $25 \%$ of the global population, particularly young women and children. Iron deficiency anaemia is caused by insufficient consumption of iron (or insufficient absorption of iron) and is a decrease in red blood cells (RBCs) or haemoglobin, leading to symptoms such as tiredness and fatigue; weakness, shortness of breath and reduced exercise tolerance (Longo and Camaschella, 2015). Iron deficiency without anaemia has also been shown to reduce endurance capacity, increase energy expenditure and impair adaptation to endurance exercise in females experiencing tissue depletion (Burden et al., 2015).Calcium also have significant effect on growth and development insufficient dietary calcium have negative impact on health and increase the risk of diseases such as osteoporosis (Kin et al., 2007; Morris et al., 2008). Zinc acts as a cofactor of various enzymes involved in macronutrient metabolism and cell replication (Soetan et al., 2010; Arinola, 2008). The primary roles of zinc appear to be in cell replication and gene expression and in nucleic acid and amino acid metabolism. Vitamins A and $\mathrm{E}$ metabolism and bioavailability are dependent on zinc status (Szabo et al., 1999).

Copper functions in the utilization of iron in an early stage of haemopoiesis. Copper deficiency results in an increase in iron in the liver, whereas an excess of copper results in a decrease in iron content of the liver, thus reflecting the role of copper in iron utilization. Copper is an essential micro-nutrient necessary for the haematologic and neurologic systems (Tan et al., 2006). It is necessary for the growth and formation of bone, formation of myelin sheaths in the nervous systems, helps in the incorporation of iron in haemoglobin, assists in the absorption of iron from the gastrointestinal tract and in the transfer of iron from tissues to the plasma (Soetan et al., 2010). Manganese has a variety of metabolic functions including enzyme activation, neurological function, skeletal system development, energy metabolism, reproductive function, and immunological function. It also serves as an antioxidant that protects cells from damage due to free radicals (Santamaria, 2008). Manganese also plays an essential role in regulation of cellular energy, bone and connective tissue growth and blood clotting (Erikson and Aschner, 2003). 
Carotenoids are known to be very efficient physical and chemical quenchers of singlet oxygen $\left({ }^{1} \mathrm{O}_{2}\right)$, as well as potent scavengers of other reactive oxygen species (ROS) (Fiedor et al., 2005). They are known to play a protective role in a number of ROS-mediated disorders, such as, i.e., cardiovascular diseases, several types of cancer or neurological, as well as photosensitive or eyerelated disorders (Fiedor and Burda, 2014). Dietary carotenoids are thought to provide health benefits in decreasing the risk of disease, particularly certain cancers and eye disease. Carotenoid appears to have potential role as antioxidants in foods and humans. Recent experimental evidences supports the role of carotenoids in enhancement immunity i.e., proliferation of $\mathrm{T}$ and $\mathrm{B}$ lymphocyte, stimulate effector $\mathrm{T}$ cell functions, and increased production of certain interleukins (Eldahshan et al., 2013). $\alpha$-tocopherol (vitamin E) is the major lipid-soluble antioxidant that maintains cell integrity by preventing lipid peroxidation in cellular membranes (Cervantes and Ulatowski, 2017; Burton et al., 1982). Vitamin E is associated with membrane stabilization and improves membrane repair (Raederstorff et al., 2015; Howard et al., 2011).

There is growing experimental evidence of the possible role of $\alpha$-tocopherol in oxidative stress-related diseases including neurological conditions such as Alzheimer's, Parkinson's and Down's syndrome (Schrag et al., 2013; Sung et al., 2004; Buhmann et al., 2004; Liu et al., 2007; Perrone et al., 2007). Ascorbic acid (Vitamin C) is known to play a crucial role in immune system function (Maggini et al., 2007; Webb and Villamor, 2007) and amino acid metabolism. It assists in lowering blood cholesterol by increasing its elimination from the body (Dave and Patil, 2017). Vitamin $\mathrm{C}$ regulates internal microenvironment my maintaining appropriate redox balance within the cell. Altered redox balance is associated with various diseases i.e., obesity, cancer, neurodegenerative diseases, hypertension and autoimmune diseases thus vitamin $\mathrm{C}$ can be used as an adjunct in treatment of these diseases (Figueroa-Méndez and RivasArancibia, 2015). Vitamin C can even overcome the effects of phytic acid, polyphenols etc., (Hurrell and Egli, 2010; Hallberg and Hulthén, 2000; Davidsson, 2003). Dietary vitamin C is also important in its ability to facilitate proper iron levels. Higher iron absorption (six folds) within individuals with high daily dietary intake of vitamin $\mathrm{C}$ has been observed (Pacier and Martirosyan, 2015; Hallberg, 1981). Fruits and vegetables offer a diverse mixture of nutrients that promote good health, and it is generally thought that they will be more beneficial to human health than dietary supplements (Cooper, 2004; Blomhoff et al., 2006). Vegetables offers a promising source and its bioavailability can be increased by employing suitable strategies (Bachrach, 2001; Maggioli and Stagi, 2017; Miller et al., 2001; Bhide et al., 2013).

Fenugreek (Trigonella foenum-graecum Linn.) an ancient medicinal herbs is used in various traditional medicinal practices throughout the world. The leaves and seeds of the plant are widely used in various food preparations and as an ingredient in medicinal preparations (Syeda et al., 2008). The seed find widespread use as condiments (Meghwal and Goswami, 2012). Fenugreek is associated with various therapeutic properties including antioxidant, anti-inflammatory, hepatoprotective effects (Kumar et al., 2012; Albasha and Azab, 2014), anti-diabetic and lipid lowering effect (Neelakantan et al., 2014). Fenugreek seeds contain high amount of carbohydrates (45$60 \%)$, proteins $(20-30 \%)$, oils $(5-10 \%)$, polyphenols, alkaloids, free amino acids, minerals including calcium and iron, vitamin $\mathrm{A}, \mathrm{B}_{1}, \mathrm{C}$ and nicotinic acids (Norziah et al., 2015). 
Recent experimental evidences have identified fenugreek as a valuable multipurpose plant with well proven therapeutic effects and as raw material for pharmaceutical industry, especially steroidal hormones (Nasroallah and Kolsum, 2013). Fenugreek seeds have been used in development of therapeutic foods especially for diabetes (Vijaykumar and Deepa, 2010; Jain et al., 2015) but its potential use to supplement micronutrient deficiencies has not yet been tried out. More research is needed to identify target bioactives and the levels required for a beneficial effect on longterm health and the prevention of chronic diseases. These studies need to compare cultivars with varying levels of bioactives as well as specific individual or combinations of bioactives in animal models and human clinical trials to identify the key targets for the development of truly health enhanced cultivars of fruit. The need of the hour to address global micronutrient malnutrition requires the need for many strategies Conventional approaches including micronutrient supplementation and fortification, has certain limitations. Promotion of suitable food based approaches to enable adequate intakes of micronutrients by much of the population includes dietary diversification strategies and use of nutrient rich foods.

Dietary diversification to combat micronutrient malnutrition is only possible by the promotion of functional foods. Furthermore, health-promoting compounds from fruits and vegetables, either as pure compounds or as standardized extracts, have unmatched chemical diversity and thus can provide opportunities for exploring novel biological activities (Patil et al., 2014). As a result of an increasing demand for chemical diversity, programs screening compounds from fruits and vegetables are growing rapidly throughout the world. The main objective of the present investigation was to evaluate the genotypic difference in different fenugreek genotypes w.r.t different micronutrients and identification of potential genotypes, which could be used to overcome micronutrient deficiencies in human beings.

\section{Materials and Methods}

\section{Chemicals and reagents}

The compounds $\beta$-carotene, 2, 2'-bipyridyl, $\alpha-$ tocopherol, $\mathrm{N}$-ethylmaleimide were purchased from Himedia (India). All other chemicals and reagents used were of analytical grade.

\section{Plant material}

The present study was undertaken to investigate fenugreek genotypes w.r.t micronutrients i.e., Iron, zinc, manganese, copper, calcium, carotenoids, ascorbic acid and $\alpha$-tocopherol in seeds of different genotypes. The seeds of the fenugreek genotypes (25) under varietal trials of All India Coordinated Research Project (AICRP) on seed Spices were used in the present investigation. Fenugreek genotypes viz., AM316, UM-271, UM-222, UM-258, UM-265, UM-273, UM-274, UM-279, UM-325, IC143843, IC-143850, IC-143816, IC-066843, UM-126, RMt-303, RMt-305, Pusa early bunching, RMt-1, GM-2, RMt-2, RMt-361, RMt-143, Pant ragini, HM-355 and UM-366 were collected from Vegetable Research Centre (VRC), GBPUA\&T, Pantnagar, district Udham Singh Nagar (Uttarakhand, India).

\section{Total ascorbate (Vitamin C)}

Total ascorbate content within fenugreek genotypes was estimated by the method of Law et al., (1983). To $500 \mathrm{mg}$ powdered seed samples, $10 \%(\mathrm{w} / \mathrm{v})$ trichloroacetic acid was added and vortexed mixed. The resulting extract was kept in ice for 5 min. $10 \mu \mathrm{l} \mathrm{NaOH}$ was added and the extract centrifuged in a 
microfuge for $2 \mathrm{~min}$. The supernatant was used for the estimation of total ascorbate content. To $200 \mu \mathrm{l}$ of supernatant, $900 \mu 1200$ $\mathrm{mM} \mathrm{NaH}{ }_{2} \mathrm{PO}_{4}$ buffer ( $\mathrm{pH} 7.4$ ), and $200 \mu \mathrm{l}$ of $1.5 \mathrm{mM}$-dithiothreitol was added and mixed thoroughly. The reaction mixture was left at room temperature for $30 \mathrm{~min}$ and $200 \mu \mathrm{l}$ of 0.5 $\%$ (w/v) N-ethylmaleimide was added to remove excess DTT. Colour was developed in the reaction mixture by adding $1000 \mu \mathrm{l}$ of 10 $\%(\mathrm{w} / \mathrm{v})$ trichloroacetic acid, $800 \mu \mathrm{l}$ of $42 \%$ (v/v) O-phosphoric acid, $800 \mu \mathrm{l}$ of $65 \mathrm{mM} \mathrm{2,}$ 2'-bipyridyl in $70 \%(\mathrm{v} / \mathrm{v})$ ethanol and $400 \mu \mathrm{l}$ of $3 \%(\mathrm{w} / \mathrm{v}) \mathrm{FeCl}_{3}$. The reaction mixture votexed and were incubated at $42^{\circ} \mathrm{C}$ for 60 min. Absorbance of the resulting solution was measured at $525 \mathrm{~nm}$. Ascorbic acid (10-100 $\mu \mathrm{g}$ ) was used as the standard. Total ascorbate content within fenugreek genotypes was expressed as $\mu \mathrm{g}$ ascorbic acid equivalents $\mathrm{g}^{-1}$ fresh wt.

\section{Total $\alpha$-tocopherol (vitamin E)}

$\alpha$-Tocopherol (vitamin E) content within fenugreek genotypes was estimated by the method described by Backer et al., (1980). $500 \mathrm{mg}$ powdered seed samples were homogenized with $10 \mathrm{ml}$ mixture of petroleum ether and ethanol $(2: 1.6 ; \mathrm{v} / \mathrm{v})$ the resulting extract was centrifuged at 10,000 rpm for 20 min and the supernatant used for estimation of $\alpha$-tocopherol.

To $1 \mathrm{ml}$ of supernatant, $200 \mu \mathrm{l}$ of $2 \% 2,2$ 'bipyridyl (dissolved in ethanol) was added. The reaction mixture was mixed thoroughly and kept in the dark for $5 \mathrm{~min}$. The red colour developed within the reaction mixture was diluted with $4 \mathrm{ml}$ of distilled water and mixed well. The resulting colour (red) in the aqueous phase was measured at $520 \mathrm{~nm}$. $\alpha$-tocopherol $(10-50 \mu \mathrm{g})$ was used as the standard. The total $\alpha$-tocopherol content within fenugreek genotypes was expressed as $\mu \mathrm{g} \alpha$-tocopherol equivalents $\mathrm{g}^{-1}$ fresh wt.

\section{Total carotenoids}

Total carotenoid content in the fenugreek genotypes was estimated by the method of Jensen, (1978). Carotenoids were extracted on the basis of their solubility in acetone. $20 \mathrm{ml}$ acetone was added to 1 gram powdered seed sample and extracts were kept overnight at room temperature. The extracts were filtered through whatman no. 1 filter paper. The residue was re-dissolved (twice) in acetone and filtered again so as to facilitate complete extraction of carotenoids. The combined filtrates were partitioned (thrice) with equal volume of peroxide-free ether. The pooled ether fraction was evaporated to dryness, under reduced pressure in a rotary flask evaporator at $35^{\circ} \mathrm{C}$. The residue was dissolved in ethanol and treated with $60 \%$ aqueous $\mathrm{KOH}$. The resulting mixture was boiled for 10 min and partitioned (thrice) with ether. The combined ether fraction was evaporated to dryness and the residue re-dissolved in ethanol. The absorbance of ethanolic solution was measured at $450 \mathrm{~nm}$. $\beta$-carotene (10-200 $\mu \mathrm{g})$ was used as a standard Total carotenoid content was expressed as $\mu \mathrm{g} \beta$-carotene equivalents $\mathrm{g}^{-1}$ fresh wt.

\section{Micronutrient estimation}

\section{Digestion of seed sample}

1 gram powdered dried seed samples from different fenugreek genotypes were weighed and then transferred to digestion tubes. About $10 \mathrm{ml}$ of conc. $\mathrm{HNO}_{3}$ was added to each tube and kept overnight. The digestion tubes were, thereafter, kept on a hot plate for $10 \mathrm{~min}$. The samples were cooled and $10 \mathrm{ml}$ mixture of nitric acid- sulfuric acid- perchloric acid (10: 1: $4 \mathrm{v} / \mathrm{v} / \mathrm{v}$ ) was added in each sample. The samples were then kept on a hot plate for complete digestion. After cooling, $5 \mathrm{ml}$ of $6 \mathrm{~N}$ $\mathrm{HCl}$ was added and volume of the digests made upto $50 \mathrm{ml}$ with distilled water. The 
digests were filtered with a whatmann no. 1 filter paper and transferred to storage vials. These digested samples were analyzed for zinc, iron, copper, calcium and manganese.

Determination of iron, calcium, zinc, copper and manganese in plant samples

The micronutrients i.e., iron, calcium, zinc, copper and manganese within fenugreek genotypes were determined with the help of double beam atomic absorption spectrophotometer (ECIL, Hyderabad). The instrument settings for different elements were as follows:

\section{Statistical analysis}

Analysis of variance (ANOVA) and Duncan LSD post hoc test were carried out on the experimental values $(n=3)$ obtained in the present investigation. Correlation analysis (bivariate) was also carried out to determine the relationship between dietary antioxidants (i.e., total ascorbate, $\alpha$-tocopherol and total carotenoids) and different mineral elements (i.e., iron, calcium, zinc, copper and manganese) present within different fenugreek (Trigonella foenum-graecum L.) genotypes under investigation. Statistical analysis and graphing were carried out by the software IBM SPSS Statistics 20 (IBM Corporation) and Sigma Plot for Windows 11.0 (Systat Software, Inc.), respectively. A statistical difference at $\mathrm{p} \leq 0.05$ between genotypes under different estimations was considered to be significant.

\section{Results and Discussion}

\section{Total ascorbate content}

Total ascorbate content within fenugreek genotypes under investigation varied from $4.915 \pm 0.077$ to $51.292 \pm 0.231 \mathrm{mg}$ ascorbic acid equivalents/100 $\mathrm{g}$ dry wt. in IC-066843 and HM-355, respectively (Figure 1: A). No significant difference $(\mathrm{P} \leq 0.05)$ in total ascorbate content was observed between UM366, IC-143850 and RMt-303 (i.e., $37.611 \pm 0.363, \quad 37.379 \pm 0.096 \quad$ and $35.988 \pm 1.783 \mathrm{mg}$ ascorbic acid equivalents/100 g dry wt., respectively). Similarly no significant difference $(\mathrm{P} \leq 0.05)$ in total ascorbate content was observed between UM-265 and UM-222 (i.e., 29.379 \pm 0.811 and $29.031 \pm 0.231 \quad \mathrm{mg}$ ascorbic acid equivalents/100 g dry wt., respectively), IC143816 and UM-274 (i.e., 27.640 \pm 2.009 and $27.524 \pm 1.379 \quad \mathrm{mg}$ ascorbic acid equivalents/100 g dry wt., respectively), RMt143 and IC-143843 (i.e., 26.017 \pm 0.386 and $25.669 \pm 0.425 \mathrm{mg}$ ascorbic acid equivalents/100 g dry wt., respectively), RMt361 and UM-273 (i.e., 24.510 \pm 1.198 and $24.046 \pm 0.811 \mathrm{mg}$ ascorbic acid equivalents/100 g dry wt., respectively), RMt1 and UM-258 (i.e., $14.075 \pm 0.038$ and $13.959 \pm 0.927 \quad \mathrm{mg}$ ascorbic acid equivalents/100 g dry wt., respectively). The 25 fenugreek genotypes can be grouped into 18 distinct groups on the basis of total ascorbate content. The genotypes within the groups differed significantly $(\mathrm{P} \leq 0.05)$ w.r.t total ascorbate content.

\section{$\alpha$-Tocopherol content}

$\alpha$-Tocopherol content within fenugreek genotypes under investigation varied from $0.948 \pm 0.021$ to $43.080 \pm 1.542 \mathrm{mg} \alpha$ tocopherol/100 g dry wt. in UM-274 and RMt305, respectively (Figure 1: B). No significant difference $(\mathrm{P} \leq 0.05)$ in $\alpha$-tocopherol content was observed between Pusa early bunching and IC-143816 (i.e., 14.653 \pm 1.184 and $14.653 \pm 1.184 \mathrm{mg} \alpha$-tocopherol $/ 100 \mathrm{~g}$ dry wt., respectively). Similarly no significant difference $(\mathrm{P} \leq 0.05)$ in $\alpha$-tocopherol content was observed between UM-265, GM-2 and IC-143850 (i.e., 9.070 \pm 0.338 , 9.070 \pm 0.083 and $9.070 \pm 0.584 \mathrm{mg} \alpha$-tocopherol/100 g dry 
wt., respectively), UM-258 and UM-222 (i.e., $7.547 \pm 0.169$ and $7.547 \pm 0.507 \mathrm{mg} \alpha-$ tocopherol/100 g dry wt., respectively), UM273 and UM-271 (i.e., 6.024 \pm 0.078 and $6.024 \pm 0.338 \mathrm{mg} \alpha$-tocopherol $/ 100 \mathrm{~g}$ dry wt., respectively), Pant ragini and HM-355 (i.e., $3.486 \pm 0.169$ and $3.486 \pm 0.169 \mathrm{mg} \alpha-$ tocopherol/100 g dry wt., respectively), UM279 and UM-366 (i.e., $2.471 \pm 0.507$ and $2.471 \pm 0.169 \mathrm{mg} \alpha$-tocopherol $/ 100 \mathrm{~g}$ dry wt., respectively), RMt-143 and UM-274 (i.e., $1.455 \pm 0.169$ and $0.948 \pm 0.021 \mathrm{mg} \alpha-$ tocopherol/100 g dry wt., respectively). The 25 fenugreek genotypes can be grouped into 15 distinct groups on the basis of $\alpha$-tocopherol content. The genotypes within the groups differed significantly $(\mathrm{P} \leq 0.05) \quad$ w.r.t $\alpha$ tocopherol content.

\section{Total carotenoid content}

Total carotenoid content within fenugreek genotypes under investigation varied from $1.450 \pm 0.003$ to $8.538 \pm 0.018 \mathrm{~g}$ carotenoids $/ 100$ $\mathrm{g}$ dry wt. in UM-271 and UM-222, respectively (Figure 1: C). No significant difference $(\mathrm{P} \leq 0.05)$ in total carotenoid content was observed between UM-258 and UM-279 (i.e., $3.835 \pm 0.032$ and $3.824 \pm 0.021 \mathrm{~g}$ carotenoids $/ 100 \mathrm{~g}$ dry wt., respectively). Similarly no significant difference $(\mathrm{P} \leq 0.05)$ in total carotenoid content was observed between IC-143816 and Pant ragini (i.e., 3.505 \pm 0.069 and $3.417 \pm 0.010 \mathrm{~g}$ carotenoids $/ 100 \mathrm{~g}$ dry wt., respectively), UM-265 and RMt-361 (i.e., $3.241 \pm 0.252$ and $3.175 \pm 0.032 \mathrm{~g}$ carotenoids $/ 100 \mathrm{~g}$ dry wt., respectively), IC-143843 and Pusa early bunching (i.e., $2.956 \pm 0.040$ and $2.934 \pm 0.010 \mathrm{~g}$ carotenoids $/ 100 \mathrm{~g}$ dry wt., respectively), AM-316 and UM-126 (i.e., $2.109 \pm 0.027$ and $2.098 \pm 0.047 \mathrm{~g}$ carotenoids $/ 100 \mathrm{~g}$ dry wt., respectively), RMt-2 and UM274 (i.e., $1.967 \pm 0.010$ and $1.934 \pm 0.007 \mathrm{~g}$ carotenoids $/ 100 \mathrm{~g}$ dry wt., respectively). The 25 fenugreek genotypes can be grouped into 19 distinct groups on the basis of total carotenoid content. The genotypes within the groups differed significantly $(\mathrm{P} \leq 0.05)$ w.r.t total carotenoid content.

\section{Iron content}

The iron content in fenugreek genotypes under investigation varied from $76.56 \pm 2.421$ to $184.11 \pm 1.639 \mu \mathrm{g} / \mathrm{g}$ dry wt. in RMt-361 and RMt-143, respectively (Table 2). No significant difference $(\mathrm{P} \leq 0.05)$ in iron content was observed between IC-066843 and RMt305 (i.e., $177.93 \pm 1.815$ and $176.52 \pm 2.413$ $\mu \mathrm{g} / \mathrm{g}$ dry wt., respectively). Similarly no significant difference $(\mathrm{P} \leq 0.05)$ in iron content was observed between UM-325, GM-2 and RMt-2 (i.e., $143.34 \pm 1.983,143.34 \pm 1.148$ and $142.08 \pm 0.681 \mu \mathrm{g} / \mathrm{g}$ dry wt., respectively), Pant ragini and UM-222 (i.e., $109.95 \pm 2.014$ and $109.95 \pm 1.079 \mu \mathrm{g} / \mathrm{g}$ dry wt., respectively), UM-265 and RMt-303 (i.e., 100.05 \pm 1.792 and $100.05 \pm 1.977 \mu \mathrm{g} / \mathrm{g}$ dry wt., respectively), Pusa early bunching and IC-143816 (i.e., $98.82 \pm 1.066$ and $97.62 \pm 1.333 \mu \mathrm{g} / \mathrm{g}$ dry wt., respectively). The 25 fenugreek genotypes can be grouped into 19 distinct groups on the basis of observed iron content. The genotypes within the groups differed significantly $(\mathrm{P} \leq 0.05)$ w.r.t iron content.

\section{Calcium content}

The calcium content in fenugreek genotypes under investigation varied from $91.80 \pm 1.324$ to $781.20 \pm 4.790 \mu \mathrm{g} / \mathrm{g}$ dry wt. in UM-279 and RMt-143, respectively (Table 2). No significant difference $(\mathrm{P} \leq 0.05)$ in calcium content was observed between IC-143816, IC143850, RMt-361 and UM-271 (i.e., $173.61 \pm 1.032, \quad 173.07 \pm 2.013, \quad 171.45 \pm 3.661$ and $169.86 \pm 1.439 \mu \mathrm{g} / \mathrm{g}$ dry wt., respectively). Similarly no significant difference $(\mathrm{P} \leq 0.05)$ in iron content was observed between UM-265 and UM-126 (i.e., $163.41 \pm 1.542$ and $160.20 \pm 1.802 \mu \mathrm{g} / \mathrm{g}$ dry wt., respectively). The 25 fenugreek genotypes can be grouped into 
21 distinct groups on the basis of observed calcium content. The genotypes within the groups differed significantly $(\mathrm{P} \leq 0.05)$ w.r.t calcium content.

\section{Zinc content}

The zinc content in fenugreek genotypes under investigation varied from $15.18 \pm 1.148$ to $35.52 \pm 1.229 \mu \mathrm{g} / \mathrm{g}$ dry wt. in UM-222 and IC066843, respectively (Table 2). No significant difference $(\mathrm{P} \leq 0.05)$ in zinc content was observed between UM-258, RMt-143 and HM-355 (i.e., 26.28 $\pm 1.226,26.28 \pm 1.024$ and $26.28 \pm 1.330 \mu \mathrm{g} / \mathrm{g}$ dry wt., respectively). Similarly no significant difference $(\mathrm{P} \leq 0.05)$ in zinc content was observed between Pant ragini and UM-366 (i.e., 23.94 \pm 0.807 and $23.58 \pm 1.518 \mu \mathrm{g} / \mathrm{g}$ dry wt., respectively), RMt2 and IC-143816 (i.e., 19.32 \pm 0.902 and $19.23 \pm 0.458 \mu \mathrm{g} / \mathrm{g}$ dry wt., respectively), RMt361, UM-274 and UM-126 (i.e., 18.06 \pm 0.573 , $17.88 \pm 0.505$ and $17.79 \pm 0.746 \mu \mathrm{g} / \mathrm{g}$ dry wt., respectively), RMt-303 and RMt-305 (i.e., $17.34 \pm 1.232$ and $16.89 \pm 0.383 \mu \mathrm{g} / \mathrm{g}$ dry wt., respectively), RMt-1 and UM-222 (i.e., $15.36 \pm 0.487$ and $15.18 \pm 1.148 \mu \mathrm{g} / \mathrm{g}$ dry wt., respectively). The 25 fenugreek genotypes can be grouped into 17 distinct groups on the basis of observed zinc content. The genotypes within the groups differed significantly $(\mathrm{P} \leq 0.05)$ w.r.t zinc content.

\section{Copper content}

The copper content in fenugreek genotypes under investigation varied from $0.05 \pm 0.006$ to $5.82 \pm 0.037 \mu \mathrm{g} / \mathrm{g}$ dry wt. in UM-222 and IC143850, respectively (Table 2). No significant difference $(\mathrm{P} \leq 0.05)$ in zinc content was observed between IC-143850, GM-2 and UM265 (i.e., 5.28 $\pm 0.037, \quad 5.82 \pm 0.053$ and $5.82 \pm 0.034 \mu \mathrm{g} / \mathrm{g}$ dry wt., respectively). Similarly no significant difference $(\mathrm{P} \leq 0.05)$ in copper content was observed between UM325 and RMt-143 (i.e., $4.53 \pm 0.042$ and
$4.53 \pm 0.028 \mu \mathrm{g} / \mathrm{g}$ dry wt., respectively), UM274, IC-066843 and HM-355 (i.e., $3.27 \pm 0.027,3.27 \pm 0.041$ and $3.27 \pm 0.034 \mu \mathrm{g} / \mathrm{g}$ dry wt., respectively), UM-273, UM-271, IC143843 and IC-143816 (i.e., 2.61 \pm 0.027 , $2.61 \pm 0.029,2.61 \pm 0.019$ and $2.61 \pm 0.017 \mu \mathrm{g} / \mathrm{g}$ dry wt., respectively), RMt-303 and Pusa early bunching (i.e., $1.35 \pm 0.02$ and $1.35 \pm 0.016 \mu \mathrm{g} / \mathrm{g}$ dry wt., respectively), UM-366, UM-358, RMt-2, RMt-305 and UM-222 (i.e., $0.06 \pm 0.001, \quad 0.06 \pm 0.001, \quad 0.06 \pm 0.001$, $0.06 \pm 0.007$ and $0.054 \pm 0.006 \mu \mathrm{g} / \mathrm{g}$ dry wt., respectively). The 25 fenugreek genotypes can be grouped into 12 distinct groups on the basis of observed zinc content. The genotypes within the groups differed significantly $(\mathrm{P} \leq 0.05)$ w.r.t zinc content.

\section{Manganese content}

The manganese content in fenugreek genotypes under investigation varied from $0.66 \pm 0.028$ to $25.65 \pm 0.695 \mu \mathrm{g} / \mathrm{g}$ dry wt. in UM-274 and RMt-143, respectively (Table 2). No significant difference $(\mathrm{P} \leq 0.05)$ in manganese content was observed between RMt-143 and HM-355 (i.e., 25.65 \pm 0.695 and $25.65 \pm 0.217 \mu \mathrm{g} / \mathrm{g}$ dry wt., respectively). Similarly no significant difference $(\mathrm{P} \leq 0.05)$ in manganese content was observed between UM-366 and Pant ragini (i.e., 23.13 \pm 0.281 and $23.13 \pm 0.728 \mu \mathrm{g} / \mathrm{g}$ dry wt., respectively), RMt-2 and Pusa early bunching (i.e., $15.66 \pm 0.764$ and $15.66 \pm 0.548 \mu \mathrm{g} / \mathrm{g}$ dry wt., respectively), RMt-361 and GM-2 (i.e., $10.65 \pm 0.363$ and $10.65 \pm 0.573 \mu \mathrm{g} / \mathrm{g}$ dry wt., respectively), UM-126, RMt-305, RMt-303, RMt-1, IC-143843 and AM-316 (i.e., $5.67 \pm 0.390, \quad 5.67 \pm 0.573, \quad 5.67 \pm 0.666$, $5.67 \pm 0.571,5.67 \pm 0.394$ and $5.67 \pm 0.017 \mu \mathrm{g} / \mathrm{g}$ dry wt., respectively), IC-143816 and IC066843 (i.e., $3.18 \pm 0.026$ and $3.18 \pm 0.693 \mu \mathrm{g} / \mathrm{g}$ dry wt., respectively), UM-279, UM-273, UM-271, UM-265, UM-222, IC-143850 and UM-274 (i.e., $\quad 0.66 \pm 0.021, \quad 0.66 \pm 0.016$, $0.66 \pm 0.598, \quad 0.66 \pm 0.010, \quad 0.66 \pm 0.001$, 
$0.66 \pm 0.001$ and $0.66 \pm 0.028 \mu \mathrm{g} / \mathrm{g}$ dry wt. respectively). The 25 fenugreek genotypes can be grouped into 9 distinct groups on the basis of observed manganese content. The genotypes within the groups differed significantly $\quad(\mathrm{P} \leq 0.05) \quad$ w.r.t manganese content.

\section{Total ascorbate content}

Plant based foods are an important source of ascorbic acid (vitamin C). Ascorbic acid is important in metabolism of various metabolites including folic acid, tyrosine, tryptophan etc. It also have definite role in metabolism of cholesterol (Dave and Patil. 2017) i.e., assist in lowering of blood cholesterol levels.

Ascorbic acid helps in absorption of iron thereby regulating iron levels in the body. The ascorbate content within fenugreek genotypes showed a positive correlation with $\alpha$ tocopherol and carotenoid content (i.e., 0.114 and 0.061 , respectively). It also showed a significant $(\mathrm{p} \leq 0.05)$ positive correlation with manganese content (0.298) and iron content (0.062) among the genotypes (Figure 2: A).

Vitamin $\mathrm{C}$ is a multifunctional vitamin, especially its potential role as an antioxidant and its health promoting effects in prevention of cancer and blood pressure. Its crucial role in providing overall immunity is well documented (Maggini et al., 2007; Webb and Villamor, 2007). The fenugreek genotypes under investigation showed a significant amount of ascorbate within the genotypes, which may be associated with availability of other essential micronutrients especially iron, manganese, $\alpha$-tocopherol and carotenoids as observed by the positive correlation of these micronutrients with total ascorbate content within the genotypes. The results clearly shows that fenugreek genotypes with high ascorbate content i.e., HM-355, UM-126,
RMt-305 and Pant ragini can be used as a potential functional food and may provide desired health benefits especially against iron deficiency anaemia, maintenance of cholesterol levels and overall immunity. Presence of significant amount of vitamin $\mathrm{C}$ in fenugreek seeds has also been reported by Leela and Shafeekh (2008) and Srinivasan (2006). Thus ascorbate along with other antioxidants i.e., $\alpha$-tocopherol and carotenoids may be responsible for imparting functional food status to fenugreek.

\section{a-tocopherol content}

$\alpha$-Tocopheral (vitamin E) is a major lipidsoluble antioxidant which plays an important role in maintaining cellular integrity by preventing membrane lipid peroxidation (Cervantes and Ulatowski 2017). It has an essential role in preventing cellular damage caused by various oxidative stress associated diseases viz., Alzheimer, Parkinson's disease etc. Recent studies have shown a positive correlation between vitamin $E$ supplementation and prevention of diseases like atherosclerosis, cataract, cardiovascular diseases, neural tube defects and cancer.

The vitamin $\mathrm{E}$ content within fenugreek genotypes under investigation showed a significant $(\mathrm{p} \leq 0.01)$ positive correlation (0.328) with total carotenoids another important lipid-soluble antioxidant. It also showed a positive correlation with ascorbate, iron and calcium content (i.e., 0.114, 0.213 and 0.036 , respectively) within the genotypes (Figure 2: B). The results clearly show that fenugreek genotypes with high vitamin $\mathrm{E}$ content viz., RMt-305, RMt-303, Pusa early bunching and IC-143816 are rich source of vitamin $E$ and can be used for vitamin $E$ supplementation and thereby may provide potential health benefits in prevention of neurological and other oxidative stress associated diseases. 
Fig.1 (A) Total ascorbate content; (B) $\alpha$-tocopherol content; (C) Total carotenoid content in in different fenugreek (Trigonella foenum-graecum L.) genotypes. Data shown are mean value \pm standard error $(n=3)$. (* Note: The values with same superscript are not significantly different at $(\mathrm{P} \leq 0.05)$ according to Duncan LSD post hoc analysis)
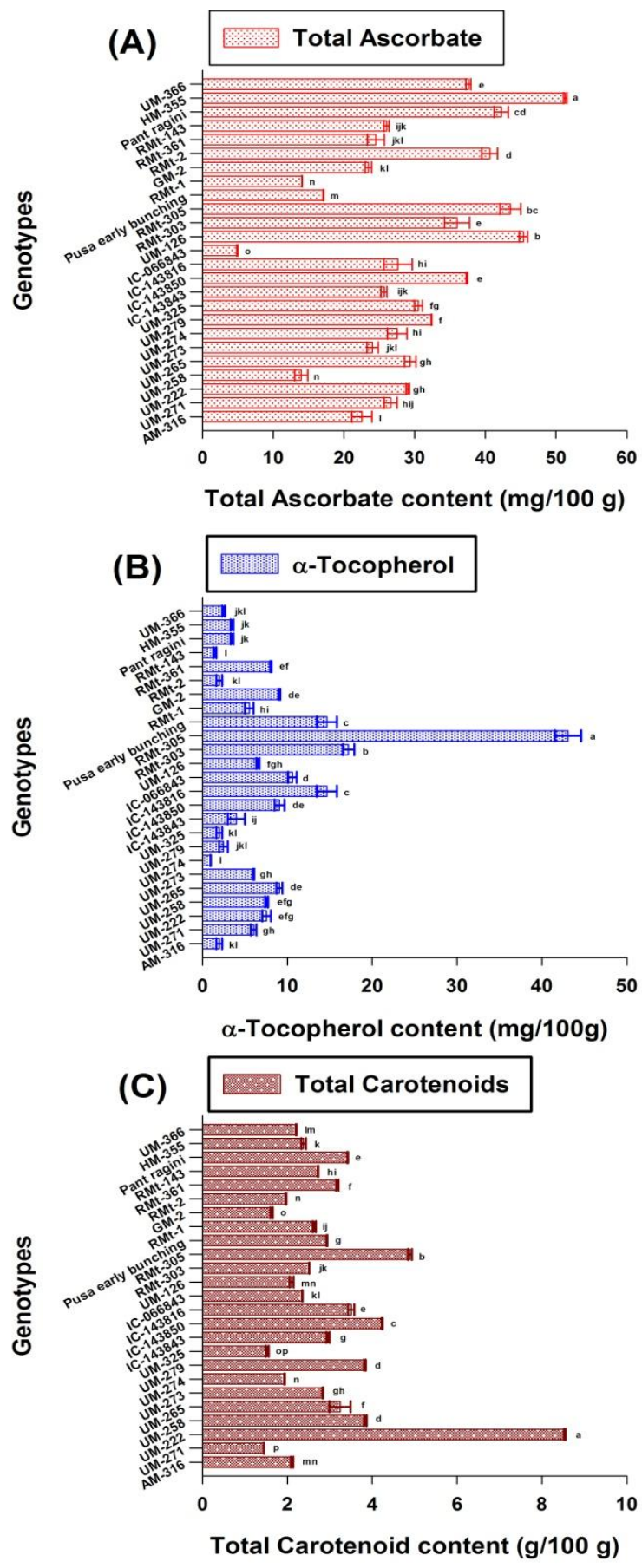
Fig.2 Correlation analysis (A): Between total ascorbate content and mineral elements (i.e., iron, calcium, zinc, copper \& manganese, respectively); (B): Between $\alpha$-Tocopherol content and mineral elements (i.e., iron, calcium, zinc, copper \& manganese, respectively); (C): Between Total carotenoid content and mineral elements (i.e., iron, calcium, zinc, copper \& manganese, respectively), within seeds of different fenugreek (Trigonella foenum-graecum L.) genotypes. Data shown are mean value \pm standard error $(n=3)$
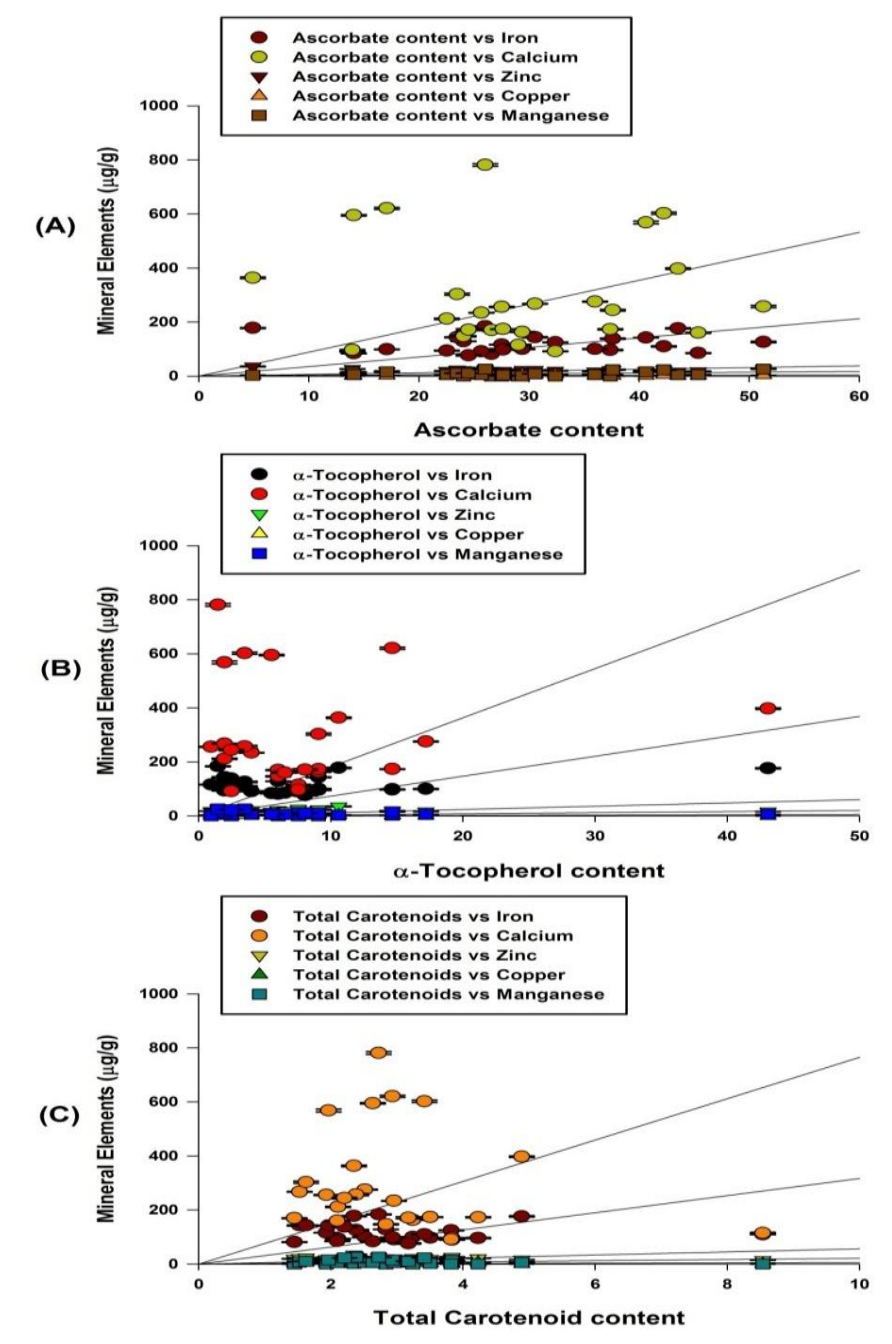

Table.1 Instrument settings for determination of different elements

\begin{tabular}{|l|c|c|c|c|}
\hline \multicolumn{1}{|c|}{ Element } & $\begin{array}{c}\text { Wavelength } \\
(\mathbf{n m})\end{array}$ & $\begin{array}{c}\text { Slit width } \\
(\mathbf{n m})\end{array}$ & Light source & Flame type \\
\hline Iron (Fe) & 248.3 & 0.2 & Cathode Lamp & Air acetylene flame (Oxidizing) \\
\hline Calcium (Ca) & 422.7 & 0.2 & -do- & -do- \\
\hline Zinc (Zn) & 213.9 & 1 & - -do- & -do- \\
\hline Copper (Cu) & 324.8 & 0.2 & -do- & -do- \\
\hline $\begin{array}{l}\text { Manganese } \\
\text { (Mn) }\end{array}$ & 279.5 & 0.2 & -do- & -do- \\
\hline
\end{tabular}


Table.2 Micronutrient content in different fenugreek (Trigonella foenum-graecum L.) genotypes. Data shown below are mean value \pm standard error $(\mathrm{n}=3)$

\begin{tabular}{|c|c|c|c|c|c|c|}
\hline S. No. & Genotypes & $\begin{array}{l}\text { Iron } \\
(\mu \mathrm{g} / \mathrm{g})\end{array}$ & $\begin{array}{c}\text { Calcium } \\
(\mu \mathrm{g} / \mathrm{g})\end{array}$ & $\begin{array}{l}\text { Zinc } \\
(\mu \mathrm{g} / \mathrm{g})\end{array}$ & $\begin{array}{c}\text { Copper } \\
(\mu \mathrm{g} / \mathrm{g})\end{array}$ & $\begin{array}{c}\text { Manganese } \\
(\mu \mathrm{g} / \mathrm{g})\end{array}$ \\
\hline 1 & AM-316 & $93.87 \pm 1.558^{\mathrm{kl}}$ & $211.71 \pm 2.499^{n}$ & $19.41 \pm 0.681^{\mathrm{ijk}}$ & $1.98 \pm 0.028^{\mathrm{g}}$ & $5.67 \pm 0.017^{\mathrm{g}}$ \\
\hline 2 & UM-271 & $81.51 \pm 1.148^{\circ}$ & $169.86 \pm 1.439^{\circ}$ & $19.77 \pm 0.487^{\text {hij }}$ & $2.61 \pm 0.029^{f}$ & $0.66 \pm 0.598^{i}$ \\
\hline 3 & UM-222 & $109.95 \pm 1.079^{\mathrm{h}}$ & $115.11 \pm 2.222^{r}$ & $15.18 \pm 1.148^{\mathrm{m}}$ & $0.054 \pm 0.006^{\mathrm{k}}$ & $0.66 \pm 0.001^{i}$ \\
\hline 4 & UM-258 & $90.15 \pm 1.547^{\mathrm{m}}$ & $96.87 \pm 1.216^{\mathrm{s}}$ & $26.28 \pm 1.226^{\mathrm{b}}$ & $0.06 \pm 0.001^{\mathrm{k}}$ & $13.17 \pm 0.478^{\mathrm{d}}$ \\
\hline 5 & UM-265 & $100.05 \pm 1.792^{\mathrm{i}}$ & $163.41 \pm 1.542^{\mathrm{p}}$ & $22.50 \pm 0.545^{\mathrm{def}}$ & $5.82 \pm 0.034^{\mathrm{a}}$ & $0.66 \pm 0.010^{i}$ \\
\hline 6 & UM-273 & $128.49 \pm 0.866^{\mathrm{e}}$ & $147.33 \pm 2.115^{\mathrm{q}}$ & $21.60 \pm 0.669^{\text {etg }}$ & $2.61 \pm 0.027^{\mathrm{f}}$ & $0.66 \pm 0.016^{1}$ \\
\hline 7 & UM-274 & $116.13 \pm 0.923^{\mathrm{g}}$ & $255.72 \pm 1.723^{\mathrm{k}}$ & $17.88 \pm 0.505^{\mathrm{kl}}$ & $3.27 \pm 0.027^{\mathrm{e}}$ & $0.66 \pm 0.028^{i}$ \\
\hline 8 & UM-279 & $124.77 \pm 1.232^{\mathrm{f}}$ & $91.80 \pm 1.324^{\mathrm{t}}$ & $20.04 \pm 1.033^{\mathrm{ghi}}$ & $5.19 \pm 0.066^{\mathrm{b}}$ & $0.66 \pm 0.021^{\mathrm{i}}$ \\
\hline 9 & UM-325 & $143.34 \pm 1.983^{c}$ & $267.51 \pm 1.150^{\mathrm{j}}$ & $22.86 \pm 0.613^{\text {cde }}$ & $4.53 \pm 0.042^{c}$ & $8.16 \pm 0.366^{f}$ \\
\hline 10 & IC-143843 & $91.41 \pm 2.014^{\mathrm{lm}}$ & $234.24 \pm 1.033^{\mathrm{m}}$ & $21.06 \pm 1.258^{\mathrm{fgh}}$ & $2.61 \pm 0.019^{\mathrm{f}}$ & $5.67 \pm 0.394^{\mathrm{g}}$ \\
\hline 11 & IC-143850 & $96.36 \pm 2.101^{\mathrm{jk}}$ & $173.07 \pm 2.013^{\circ}$ & $21.96 \pm 0.675^{\mathrm{ef}}$ & $5.82 \pm 0.037^{\mathrm{a}}$ & $0.66 \pm 0.001^{i}$ \\
\hline 12 & IC-143816 & $97.62 \pm 1.333^{\mathrm{ij}}$ & $173.61 \pm 1.032^{\circ}$ & $19.23 \pm 0.458^{\mathrm{ijk}}$ & $2.61 \pm 0.017^{\mathrm{f}}$ & $3.18 \pm 0.026^{\mathrm{h}}$ \\
\hline 13 & IC-066843 & $177.93 \pm 1.815^{\mathrm{b}}$ & $363.60 \pm 2.958^{\mathrm{g}}$ & $35.52 \pm 1.229^{\mathrm{a}}$ & $3.27 \pm 0.041^{\mathrm{e}}$ & $3.18 \pm 0.693^{h}$ \\
\hline 14 & UM-126 & $85.23 \pm 1.541^{\mathrm{n}}$ & $160.20 \pm 1.802^{\mathrm{p}}$ & $17.79 \pm 0.746^{\mathrm{kl}}$ & $0.69 \pm 0.07^{\mathrm{i}}$ & $5.67 \pm 0.390^{\mathrm{g}}$ \\
\hline 15 & RMt-303 & $100.05 \pm 1.977^{i}$ & $275.58 \pm 1.529^{i}$ & $17.34 \pm 1.232^{1}$ & $1.35 \pm 0.02^{\mathrm{h}}$ & $5.67 \pm 0.666^{\mathrm{g}}$ \\
\hline 16 & RMt-305 & $176.52 \pm 2.413^{b}$ & $397.50 \pm 2.674^{\mathrm{f}}$ & $16.89 \pm 0.383^{1}$ & $0.06 \pm 0.007^{\mathrm{k}}$ & $5.67 \pm 0.573^{g}$ \\
\hline 17 & Pusa early bunching & $98.82 \pm 1.066^{1 \mathrm{j}}$ & $620.70 \pm 3.647^{b}$ & $18.24 \pm 0.987^{\mathrm{jk}}$ & $1.35 \pm 0.016^{\mathrm{h}}$ & $15.66 \pm 0.548^{c}$ \\
\hline 18 & RMt-1 & $83.97 \pm 1.064^{\mathrm{no}}$ & $594.90 \pm 2.480^{\mathrm{d}}$ & $15.36 \pm 0.487^{\mathrm{m}}$ & $0.60 \pm 0.091^{\mathrm{j}}$ & $5.67 \pm 0.571^{\mathrm{g}}$ \\
\hline 19 & GM-2 & $143.34 \pm 1.148^{\mathrm{c}}$ & $303.00 \pm 3.904^{\mathrm{h}}$ & $24.30 \pm 0.712^{c}$ & $5.82 \pm 0.053^{\mathrm{a}}$ & $10.65 \pm 0.573^{\mathrm{e}}$ \\
\hline 20 & RMt-2 & $142.08 \pm 0.681^{c}$ & $568.50 \pm 5.012^{\mathrm{e}}$ & $19.32 \pm 0.902^{\mathrm{ijk}}$ & $0.06 \pm 0.001^{\mathrm{k}}$ & $15.66 \pm 0.764^{c}$ \\
\hline 21 & RMt-361 & $76.56 \pm 2.421^{p}$ & $171.45 \pm 3.661^{\circ}$ & $18.06 \pm 0.573^{\mathrm{kl}}$ & $0.63 \pm 0.02^{\mathrm{ij}}$ & $10.65 \pm 0.363^{\mathrm{e}}$ \\
\hline 22 & RMt-143 & $184.11 \pm 1.639^{\mathrm{a}}$ & $781.20 \pm 4.790^{\mathrm{a}}$ & $26.28 \pm 1.024^{\mathrm{b}}$ & $4.53 \pm 0.028^{c}$ & $25.65 \pm 0.695^{\mathrm{a}}$ \\
\hline 23 & Pant ragini & $109.95 \pm 2.014^{\mathrm{h}}$ & $602.40 \pm 4.114^{\mathrm{c}}$ & $23.94 \pm 0.807^{\mathrm{cd}}$ & $3.9 \pm 0.028^{\mathrm{d}}$ & $23.13 \pm 0.728^{b}$ \\
\hline 24 & HM-355 & $126.03 \pm 2.465^{\mathrm{ef}}$ & $257.31 \pm 3.856^{\mathrm{k}}$ & $26.28 \pm 1.33^{\mathrm{b}}$ & $3.27 \pm 0.034^{\mathrm{e}}$ & $25.65 \pm 0.217^{\mathrm{a}}$ \\
\hline 25 & UM-366 & $138.39 \pm 1.990^{\mathrm{d}}$ & $243.90 \pm 2.733^{1}$ & $23.58 \pm 1.518^{\mathrm{cd}}$ & $0.06 \pm 0.001^{\mathrm{k}}$ & $23.13 \pm 0.281^{\mathrm{b}}$ \\
\hline
\end{tabular}

* Note: The values with same superscript are not significantly different at $(\mathrm{P} \leq 0.05)$ according to Duncan LSD post hoc analysis 


\section{Total carotenoid content}

Carotenoids serves as potent quenchers of reactive oxygen species (Fiedor et al., 2005) which are associated with various oxidative stress mediated disorders viz., cardiovascular, neurological diseases as well as various types of cancers. Dietary carotenoids provides health benefits and are derived from various plant based sources i.e., fruits and vegetables. They mainly function as antioxidants. There is growing experimental evidence in the possible role of carotenoids as potential mediator of various immune responses (Eldahshan et al., 2013).

Total carotenoid content within fenugreek genotypes under investigation showed a significant $(\mathrm{p} \leq 0.01)$ positive correlation (0.328) with $\alpha$-tocopherol content another important group of lipid-soluble antioxidant in fenugreek (Figure 2: C). Presence of carotenoids ( $\beta$-carotene) within fenugreek has also been reported by Srinivasan, 2006. The results clearly show the presence of significant amount of carotenoids within seeds of different fenugreek genotypes. The genotypes with high carotenoid content viz., UM-222, RMt-305 and IC-143850 may be utilized as potential functional foods particularly in combating vitamin A malnutrition as carotenoids are an important precursor of vitamin A.

\section{Iron content}

Iron $(\mathrm{Fe})$ is an essential micronutrient in human nutrition and is the main factor responsible for occurrence of iron deficiency anaemia in humans. Plants and plant based foods are an important source of micronutrients including iron, but the bioavailability of iron from plant based foods may be influenced by various dietary factors such as inhibitors and enhancers of iron absorption. Presence of iron in fenugreek seeds has also been reported by Doshi et al., 2012 and by Shakuntala et al., 2011 in seed endosperm of fenugreek.

The iron content within the fenugreek genotypes under investigation showed a significant $(\mathrm{p} \leq 0.01)$ positive correlation with other micronutrients viz., calcium, zinc and manganese (i.e., $0.408,0.502$ and 0.299, respectively). There was also a positive correlation between iron and total ascorbate, $\alpha$-tocopherol content (i.e., 0.062 and 0.213, respectively) within the genotypes (Figure 2: A \& B). This clearly shows that fenugreek seeds may serve as an important source of iron supplementation and may help in combating dietary iron deficiency with enhanced absorption particularly in presence of vitamin C. Thus fenugreek genotypes with high iron content viz., RMt-143, IC-066843 and RMt-305 may serve as an important dietary source of iron along with other micronutrients.

\section{Calcium content}

Calcium serves as an important factor in human nutrition due to its role in bone formation and regulatory role in cellular metabolism (Linder, 1991). Although milk and milk products serves as the major source of dietary calcium requirement within humans (Chan et al., 1995), vegetables also serves as an important source to meet dietary calcium requirement. But the bioavailability of calcium depends upon various factors including presence of chelators like phytic acid and oxylate within plants (Weaver and Heaney, 1991).

The calcium content within fenugreek genotypes under investigation showed a significant $(\mathrm{p} \leq 0.01)$ positive correlation with other micronutrients viz., iron and manganese (i.e., 0.408 and 0.576 , respectively). A positive correlation between calcium and $\alpha$ - 
tocopherol (Figure 2B), zinc content (i.e., 0.036 and 0.095 , respectively) was also observed among the genotypes. Dietary calcium is known to assist in iron utilization (Fleck, 1976) apart from playing essential role in nerve transmission and muscle functioning. The results of the present investigation clearly show that fenugreek seeds are a potential source of dietary calcium along with other important micronutrients and therefore can favourably affect human health in general. Fenugreek genotypes with high calcium content viz., RMt-143, Pusa early bunching and Pant ragini could be utilized as a functional food to combact micronutrient malnutrition especially of calcium and iron faced by millions in developing and underdeveloped countries.

\section{Zinc content}

Zinc (Zn) along with other micronutrients plays an important role in human nutrition. Zinc serves as a cofactor for different enzymes involved in a variety of metabolic processes including carbohydrate, lipid and protein metabolism. Generally the zinc content in foods is low and its availability depends upon several physiological and dietary factors (Camera and Amaro, 2003).

The zinc content within fenugreek genotypes under investigation showed a significant $(p \leq 0.01)$ positive correlation with other micronutrients viz., iron, copper and manganese content (i.e., 0.502, 0.407 and 0.339 , respectively) within the genotypes. Zinc is a multifunctional micronutrient with an important role in tissue repair and wound healing apart from its effects on insulin action. The results clearly show that fenugreek may serve as an important dietary source of zinc along with other essential micronutrients. Fenugreek genotypes with high zinc content viz., IC-066843, RMt-143 and HM-355 may well be utilized as an important functional food especially w.r.t zinc and other micronutrient nutrition and may favourably affect human nutrition.

\section{Copper content}

Copper is an essential micronutrient required for proper functioning of haematological and neurological systems (Tan et al., 2006). It is also required for iron incorporation in haemoglobin apart from assisting in iron absorption and transfer. Copper acts as a cofactor for enzymes involved in blood clotting, signal transduction etc. (Kim et al., 2008). Clinical disorders associated with deficiency of copper include heart failure, anaemia and impaired reproductive system (Soetan et al., 2010). Copper is also known to regulate cholesterol biosynthesis and thereby its concentration within blood (Lei et al., 2017).

The copper content within fenugreek genotypes under investigation showed a significant $(\mathrm{p} \leq 0.01)$ positive correlation with zinc content (i.e., 0.407). There was also a positive correlation between copper and iron content (i.e., 0.189) within the genotypes. The results clearly show that fenugreek is an important dietary source of micronutrients including copper. The fenugreek genotypes with high copper content viz., IC-143850, GM-2, UM-265 and UM-279 may serve as an important dietary source of available copper along with other micronutrients and thus have a favourable health promoting affect.

\section{Manganese content}

Manganese as a micronutrient is required for carbohydrate and lipid metabolism, growth, reproduction and development of skeletal system. It serves as a cofactor in enzymes i.e., pyruvate carboxylase, superoxide dismutase etc. Manganese has a variety of metabolic functions including enzyme activation 
especially enzymes of protein and fat metabolism. It is known to play an important role in skeletal system development apart from having neurological, reproductive and immunological functions (Soetan et al., 2010). It also serves as an antioxidant that protects cells from damage due to free radicals (Santamaria, 2008)

The manganese content within fenugreek genotypes under investigation showed a significant $(\mathrm{p} \leq 0.01)$ positive correlation with iron, calcium and zinc content (i.e., 0.299, 0.576 and 0.339 , respectively). Manganese content among the genotypes also showed a significant $(\mathrm{p} \leq 0.05)$ positive correlation (Figure 2: A) with ascorbate content (0.289). Presence of $\mathrm{Mn}$ in fenugreek has also been reported by Shakuntala et al., 2011. The results clearly reveal that fenugreek genotypes vary significantly w.r.t Mn content along with other micronutrients. The genotypes with high manganese content viz., RMt-143, HM-355, UM-366 and Pant ragini may well be utilized as functional food with significant amount of micronutrients including manganese.

The present investigation clearly reveals functional food potential of fenugreek especially w.r.t micronutrients i.e., vitamin $\mathrm{C}$, vitamin $\mathrm{E}$, total carotenoids, iron, calcium, zinc, copper and manganese supplementation. Fenugreek genotypes viz., RMt-305, Pant ragini, RMt-143, Pusa early bunching, IC066843, GM-2 and HM-355 with high micronutrients may be utilized as potential source of dietary micronutrients. The results also reveal that the genotypes vary significantly w.r.t different micronutrients thereby their availability for micronutrient supplementation. The micronutrients also showed a significant positive correlation among themselves thereby clearly showing that they may have significant effect on their bioavailability among themselves upon digestion and subsequent absorption, for example a positive association between iron, total ascorbate, calcium, zinc and manganese was observed among the fenugreek genotypes under investigation. Thus the findings of the present investigation may help in identification of potential fenugreek genotypes which may be utilized in combating micronutrient malnutrition by dietary supplementation of genotypes with high micronutrient content.

\section{Conflict of interest}

The authors declare no conflict of interests regarding the publication of this paper.

\section{Acknowledgements}

The financial support provided by Council of Scientific and Industrial Research (CSIR) and the infrastructural grant provided by DST (Department of Science and Technology, Govt. of India) is duly acknowledged.

\section{References}

Akeredolu, I.A., Oguntona, B.E., Okafor, C., and Osisanya, O.J. 2011. Iron, Zinc, and Copper malnutrition among primary school children in Lagos, Nigeria. Food and Nutrition Sciences. 2: 1063-1070.

Albasha, M.O., and Azab, A.E. 2014. Effect of cadmium on the liver and amelioration by aqueous extracts of fenugreek seeds, rosemary, and cinnamon in guinea pigs: Histological and biochemical study. 2(2): 7-17.

Arinola, O.G. 2008. Essential trace elements and metal binding proteins in Nigerian consumers of alcoholic beverages. Pak. J. Nutr. 7(6): 763-765.

Bachrach, L.K. 2001. Acquisition of optimal bone mass in childhood and adolescence. Trends Endocrinol Metab. $12: 22-28$. 
Backer, H., Frank, O., Angells, B.D., and Feingold, S. 1980. Plasma tocopherol in man at various times after ingesting free or ocetylaned tocopherol. Nutr. Rep. Int. 21: 531-536.

Bailey, R.L., West Jr., K.P., and Black, R.E. 2015. The Epidemiology of Global Micronutrient Deficiencies. Ann Nutr Metab. 66(2): 22-33.

Benton, D. 2008. Micronutrient status, cognition and behavioral problems in childhood. Eur J Nutr. 47(3):38-50.

Bhandari, S., and Banjara, M.R. 2015. Micronutrients Deficiency, a Hidden Hunger in Nepal: Prevalence, Causes, Consequences, and Solutions. International Scholarly Research Notices. Article ID 276469, doi: 10.1155/2015/276469.

Bhide, R., Patil, S., Shetty, S., and Narayanan, S. 2013. Comparative Bioavailability studies of calcium from different sources. Asian J Pharm Clin Res. 6(1): 147-148.

Blomhoff, R., Carlsen, M.H., Andersen, L.F., and Jacobs Jr, D.R. 2006. Health benefits of nuts: potential role of antioxidants. British Journal of Nutrition. $\quad 96(2)$ : S52-S60. DOI: 10.1017/BJN20061864.

Buhmann, C., Arlt, S., Kontush, A., MöllerBertram, T., Sperber, S., Oechsner, M., Stuerenburg, H.J., and Beisiegel, U. 2004. Plasma and CSF markers of oxidative stress are increased in Parkinson's disease and influenced by antiparkinsonian medication. Neurobiol. Dis. 15: 160-170.

Burchi, F., Fanzo, J., and Frison, E. 2011. The Role of Food and Nutrition System Approaches in Tackling Hidden Hunger. Int. J. Environ. Res. Public Health. 8: 358-373.

Burden, R.J., Morton, K., Richards, T., Whyte, G.P., and Pedlar, C.R. 2015. Is iron treatment beneficial in iron- deficient but non-anaemic (IDNA) endurance athletes? A systematic review and meta-analysis. Br J Sports Med. 49(21): 1389-97.

Burton, G.W., Joyce, A., and Ingold, K.U. 1982. First proof that vitamin $\mathrm{E}$ is major lipid-soluble, chain-breaking antioxidant in human blood plasma. Lancet. 2: 327.

Camera, F., and Amaro, M.A. 2003. Nutritional aspect of zinc availability. Int. J. Food Sci. Nutr. 54: 143-151.

Cervantes, B., and Ulatowski, L.M. 2017. Vitamin E and Alzheimer's Disease Is It Time for Personalized Medicine? Antioxidants. doi:10.3390/antiox6030045.

Chan, G.M., Hoffman, K. and McMurry, M. 1995. The effects of dairy products on bone and body composition in pubertal girls. J. Pediatr. 126: 551-556.

Cooper, D.A. 2004. Carotenoids in health and disease: recent scientific evaluations, research recommendations and the consumer. J Nutr. 134: 221-224.

Dave, K.N., and Patil, R.S. 2017. Biological Importance of Ascorbic Acid (Vitamin C) in Human Health-A Classic Review. International Journal for Research in Biology \& Pharmacy. 3(7): 1-8.

Davidsson, L. 2003. Approaches to improve iron bioavailability from complementary foods. J Nutr. 133 (5 Suppl 1): 1560S-1562S.

Doshi, M., Mirza, A., Umarji, B., and Karambelkar, R. 2012. Effect of Trigonella foenum-graecum (Fenugreek/ Methi) on Hemoglobin Levels in Females of Child Bearing Age. Biomedical Research. 23 (1): 4750.

Eldahshan, O.A., Abdel Nasser, B., and Singab, A.N.B. 2013. Carotenoids. Journal of Pharmacognosy and Phytochemistry. 2(1): 225-234. 
Erikson, K.M., and Aschner, M. 2003. Manganese neurotoxicity and glutamate-GABA interaction. Neurochem Int. 43: 475-80.

Fanzo, J. 2015. Ethical issues for human nutrition in the context of global food security and sustainable development. Global Food Security. 7: 15-23.

Fiedor, J., and Burda, K. 2014. Potential Role of Carotenoids as Antioxidants in Human Health and Disease. Nutrients. 6: 466-488.

Fiedor, J., Fiedor, L., Haessner, R., and Scheer, H. 2005. Cyclic ednoperoxides of $\beta$-carotene, potential pro-oxidants, as products of chemical quenching of singlet oxygen. Biochim. Biophys. Acta. 1709: 1-4.

Figueroa-Méndez, R., and Rivas-Arancibia, S. 2015. Vitamin C in Health and Disease: Its Role in the Metabolism of Cells and Redox State in the Brain. Frontiers in Physiology...www.frontiersin.org 6 (397).

Fleck, H., 1976. Introduction to Nutrition. $4^{\text {th }}$ Edn. Macmillian. Publishing Co. Inc. New York, ISBN: 00-233-82805 pp. 552.

Hallberg, L. 1981. Bioavailability of dietary iron in man. Annu Rev Nutr. 1: 123147.

Hallberg, L., and Hulthén, L. 2000. Prediction of dietary iron absorption: an algorithm for calculating absorption and bioavailability of dietary iron. Am J Clin Nutr. 71: 1147-1160.

Hill, I.D., and Mkparu, U.C. 2015. Micronutrients in Pregnancy in Lowand Middle-Income Countries. Nutrients. 7: 1744-1768.

Howard, A.C., McNeil, A.K., and McNeil, P.L. 2011. Promotion of plasma membrane repair by vitamin E. Nat Commun 2: 597.

Hurrell, R., and Egli, I. 2010. Iron bioavailability and dietary reference values. Am J Clin Nutr. 91: 1461S$1467 \mathrm{~S}$.

Jain, M., Gupta, K., Jain, P., Singh, C., and Rastogi, N. 2015. Optimization of functional food ingredients and their processing levels for preparation of upma mix. IJGHC. 4(3): 423-432.

Jensen, A. 1978. Chlorophylls and carotenoids. In J. A. Hellebust \& J. S. Caraig (Eds.), Phycological methods: Physiological and biochemical methods. Cambridge: Cambridge University Press. 59-70.

Kim, B.E., Nevitt, T., and Thiele, D.J. 2008. Mechanisms for copp.er acquisition, distribution and regulation. Nat. Chem. Biol. 4: 176-185.

Kin, C.F., Shan, W.S., Shun, L.J., Chung L.P., and Jean, W. 2007. Experience of famine and bone health in postmenopausal women. International Journal of Epidemiology. 36: 11431150.

Kumar, P., Kale, R.K., McLean, P., and Baquer, N.Z. 2012. Antidiabetic and neuroprotective effects of Trigonella foenum-graecum seed powder in diabetic rat brain. Prague Med Rep. 113(1): 33-43.

Law, M.Y., Charles, S.A., and Halliwell, B. 1983. Glutathione and ascorbic acid in spinach (Spinacea oleracea) chloroplasts. The effect of hydrogen peroxide and of paraquat. Biochem $\mathrm{J}$. 210: 899-903.

Leela, N.K., and Shafeekh, K.M. 2008. Fenugreek. In Parthasarathy, V.A., Chempakam, B. and Zachariah, T.J. (edited) Chemistry of Spices. Biddles Ltd, King's Lynn, UK, CAB International. pp. 242-59.

Lei, L., Xiaoyi, S., and Fuchang, L. 2017. Effect of dietary copper addition on lipid metabolism in rabbits. Food \& Nutrition Research. 61: 1348866. 
Linder, M.C. 1991. Nutritional biochemistry and metabolism: With clinical applications. $2^{\text {nd }}$ ed. Elsevier, New York.

Liu, Q., Xie, F., Rolston, R., Moreira, P.I., Nunomura, A., Zhu, X., Smith, M.A., Perry, G. 2007. Prevention and treatment of Alzheimer disease and aging: antioxidants. Mini Rev. Med. Chem. 7: 171-180.

Longo, D.L., and Camaschella, C. 2015. Irondeficiency anemia. $N$ Engl $J$ Med. 372(19): 1832-43.

Maggini, S., Wintergerst, E.S., Beveridge, S., and Hornig, D.H. 2007. Selected vitamins and trace elements support immune function by strengthening epithelial barriers and cellular and humoral immune responses. Br. J. Nutr. 98: S29-S35.

Maggioli, C., and Stagi, S. 2017. Bone modeling, remodeling, and skeletal health in children and adolescents: mineral accrual, assessment and treatment. Ann Pediatr Endocrinol Metab. 22: 1-5.

Meghwal, M., and Goswami, T.K. 2012. A review on the functional properties, nutritional content, medicinal utilization and potential application of fenugreek. Journal of Food Processing and Technology. 3 (9): 1-10.

Miller, D.D., and Welch, R.M. 2013. Food system strategies for preventing micronutrient malnutrition. Food Policy. 42: 115-128.

Miller, G.D., Jarvis, J.K., and McBean, L.D. 2001. The importance of meeting calcium needs with foods. J Am Coll Nutr. 20(2): 168S-185S.

Morris, J., Hawthorne, K.M., Tim-Hotze, T., Abrams, S.A., and Hirschi, K.D. 2008. Nutritional impact of elevated calcium transport activity in carrots. PNAS. 105 (5): 1431-1435.
Müller, O., and Krawinkel, M. 2005. Malnutrition and health in developing countries. CMAJ. 173(3): 279-286.

Nasroallah, M., and Kolsum, M. 2013. Physiological and pharmaceutical effects of fenugreek (Trigonella foenum-graecum L.) as a multipurpose and valuable medicinal plant. Global $\mathrm{J}$. Medicinal Plant Res. 1(2): 199-206.

Neelakantan, N., Narayanan, M., De-Souza, M.R.J., and van-Dam, R.M. 2014. Effect of fenugreek (Trigonella foenumgraecum L.) intake on glycemia: a meta-analysis of clinical trials. Nutrition Journal. 13(7): 1-11.

Norziah, M.H., Fezea, F.A., Bhat, R., and Ahmad, M. 2015. Effect of extraction solvents on antioxidant and antimicrobial properties of fenugreek seeds (Trigonella foenum-graecum L.). International Food Research Journal. 22(3): 1261-1271.

Pacier, C., and Martirosyan, D.M. 2015. Vitamin C: optimal dosages, supplementation and use in disease prevention. Functional Foods in Health and Disease. 5(3): 89-107.

Patil, B.S., Crosby, K., and Byrne, D. 2014. The Intersection of Plant Breeding, Human Health, and Nutritional Security: Lessons Learned and Future Perspectives. Hort Science. 49(2): 116127.

Perrone, S., Longini, M., Bellieni, C.V., Centini, G., Kenanidis, A., De Marco, L., Petraglia, F., and Buonocore, G. 2007. Early oxidative stress in amniotic fluid of pregnancies with Down syndrome. Clin. Biochem. 40: 177-180.

Raederstorff, D., Wyss, A., Calder, P.C., Weber, P., and Eggersdorfer, M. 2015. Vitamin E function and requirements in relation to PUFA. British Journal of Nutrition. $\quad 1-10$ doi: 10.1017/S000711451500272X. 
Santamaria, A.B. 2008. Manganese exposure, essentiality and toxicity. Indian $\mathrm{J}$ Med Res. 128: 484-500.

Schrag, M., Mueller, C., Zabel, M., Crofton, A., Kirsch, W.M., Ghribi, O., Squitti, R., and Perry, G. 2013. Oxidative stress in blood in Alzheimer's disease and mild cognitive impairment: A metaanalysis. Neurobiol. Dis. 59: 100-110.

Shakuntala, S., Naik, J.P., Jeyarani, T., Naidu, M.M., and Srinivas, P. 2011. Characterisation of germinated fenugreek (Trigonella foenumgraecum $\mathrm{L}$.) seed fractions. International Journal of Food Science \& Technology. 46(11): 2337-2343.

Soetan, K.O., Olaiya, C.O., and Oyewole, O.E. 2010. The importance of mineral elements for humans, domestic animals and plants: A review. Afr. J. Food Sci. 4(5): 200-222.

Srinivasan, K. 2006. Fenugreek (Trigonella foenum-graecum): A review of health beneficial physiological effects. Food Rev. Int. 22: 203-224.

Sung, S., Yao, Y., Uryu, K., Yang, H., Lee, V.M., Trojanowski, J.Q., and Pratico, D. 2004. Early vitamin E supplementation in young but not aged mice reduces Abeta levels and amyloid deposition in a transgenic model of Alzheimer's disease. FASEB J. 18: 323-325.

Syeda, B.B., Muhammad, I.B., and Shahabuddin, M. 2008. Antioxidant activity from the extract of fenugreek seeds. Pak. J. Anal. Environ. Chem. 9(2): 78-83.

Szabo, G., Chavan, S., Mandrekar, P., and Catalano, D. 1999. Acute alcoholic consumption attenuates IL-8 and MCP1 induction in response to ex vivo stimulation. J. Clin. Immunol. 19: 6776.

Tan, J.C., Burns, D.L., and Jones, H.R. 2006. Severe ataxia, myelopathy and peripheral neuropathy due to acquired copper deficiency in a patient with history of gastrectomy. J. Paenteral Nutr. 30: 446-450.

Tulchinsky, T.H. 2010. Micronutrient Deficiency Conditions: Global Health Issues. Public Health Reviews. 32(1): 243-255.

Vijaykumar, T., and Deepa, M. 2010. Optimization of natural polymeric enternal feed formula using response surface methodology. AJST. 1: 39-43.

Weaver, C.M., and Heaney, R.P. 1991. Isotopic exchange of ingested calcium between labeled sources. Evidence that ingested calcium does not form a common absorptive pool. Calcif. Tissue Intl. 49: 244-247.

Webb, A.L., and Villamor, E. 2007. Update: Effects of antioxidant and nonantioxidant vitamin supplementation on immune function. Nutr. Rev. 65: 181.

\section{How to cite this article:}

Naveen Chandra Pant, Manisha Tewari, Rakesh Dhoundiyal, C.S. Pandey, J.P. Singh and Sanjeev Agrawal. 2018. Evaluation of Micronutrients in Fenugreek (Trigonella foenumgraecum L.): A Viable Alternative for Micronutrient Supplementation. Int.J.Curr.Microbiol.App.Sci. 7(05): 2446-2464. doi: https://doi.org/10.20546/ijcmas.2018.705.281 